\title{
Female Cat Intravesical Sequestration after Ovariosalpingohisterectomy Using Nylon Clamp
}

\author{
Larissa Caroline Cordeiro de Andrade', Andréia Vitor Couto do Amaral'2, Camila Franco Carvalho², \\ Leuton Scharles Bonfim², Igor Ribeiro Rosa' \& Klaus Casaro Saturnino²
}

\begin{abstract}
Background: The nylon clamp, marketed as an accessory of electrical devices, has been used as an alternative method for definitive surgical hemostasis by ligature of arteriovenous vessels in ovariosalpingohisterectomy (OSH) in bitches and female cats. However, since May 2015, the Brazilian Veterinary Statutory Body (CFMV - Conselho Federal de Medicina Veterinária) banned its application, once it is a material still not regulated to be used in animals, in addition to the numerous reports of postoperative complications. This paper reports the migration of the clamp used in the OSH to the urinary bladder of the cat and the implications of the presence of the foreign body, in addition to discussing the use of this device in surgeries.

Case: A 1-year-old Persian female cat, which, three months after an elective OSH in a private veterinary clinic, presented polyuria and hematuria. The patient presented pain at abdominal palpation; in the WBC were observed leucopenia and eosinophilia, indicating a chronic inflammatory process installed; the urinalysis showed the presence of crystals, increased urinary density, milky aspect indicating presence of pus, proteinuria and hematuria; on ultrasound were observed the presence of two amorphous mobile structures inside the bladder, producing acoustic shadow, measuring approximately 0.4 and $0.6 \mathrm{~cm}$ in diameter, suggesting the presence of bladder urolithiasis. Considering the results, the patient was sent for a cystotomy. The association of acepromazine $(0.02 \mathrm{mg} / \mathrm{kg})$, midazolam $(0.2 \mathrm{mg} / \mathrm{kg})$, morphine $(0.2 \mathrm{mg} / \mathrm{kg})$ and ketamine $(10 \mathrm{mg} / \mathrm{kg})$ was used intramuscularly as preanesthetic medication. For anesthetic induction, $5 \mathrm{mg} / \mathrm{kg}$ of propofol was applied intravenously, in addition to epidural anesthesia with $1 \mathrm{~mL} / 4 \mathrm{~kg}$ of lidocaine along $0.1 \mathrm{mg} / \mathrm{kg}$ of morphine and, for maintenance, isoflurane in oxygen at $100 \%$ was used. Then, a four-centimeter retro-umbilical incision was performed to exhibit the bladder. After the incision on the ventral aspect of the bladder wall, a nylon clamp with approximately $0.8 \mathrm{~cm}$, present in the lumen was found and removed. The seromuscular synthesis of the bladder was with a 3-0 mononylon simple continuous suture, the muscle with a 2-0 mononylon sultan pattern, and in the skin an interrupted simple suture using 2-0 nylon was performed. Postoperative care comprised by amoxicillin with potassium clavulanate $(15 \mathrm{mg} / \mathrm{kg}$, orally, $8 / 8 \mathrm{~h}$, $7 \mathrm{~d})$, meloxican $(0.15 \mathrm{mg} / \mathrm{kg}$, orally, $24 / 24 \mathrm{~h}, 4 \mathrm{~d})$ and tramadol $(12 \mathrm{mg} / \mathrm{kg}$, orally, $12 / 12 \mathrm{~h}, 4 \mathrm{~d})$. After ten days, surgical stitches were removed, with good healing and clinical improvement, as well as remission of the symptomatology reported on anamnesis and physical examination.

Discussion: The pathophysiology of the nylon clip migration probably occurred in a similar way to the intravesical migration of intrauterine devices (IUDs) to the abdominal cavity, bladder and intestine, in women. According to reports, it is a progressive event, in which several factors may be involved, mainly: inadequate implantation of devices, uterine infections, use of contaminated medical instruments, among others, followed by an inflammatory process, perforation of the uterine wall by the device, adhesions and migration to adjacent structures. In the present report, it is believed that the clamp lock failed in the procedure performed by the veterinarian responsible for OSH, with subsequent loosening and detachment, and migration to the urinary bladder, an organ located ventrally to the uterine body. However, the following hypotheses can also be raised: pregnancy at the moment of castration, followed by uterine stump retraction and release of the clamp; contamination of surgical instruments; postoperative infections and adhesions involving the bladder.
\end{abstract}

Keywords: bladder, foreign body, felines, $\mathrm{OSH}$.

DOI: $10.22456 / 1679-9216.102087$ 


\section{INTRODUCTION}

In recent years, nylon 6.6 clamp, a polymer resulting from the reaction between a diamine (hexamethylenediamine) and a dihydrate (adipic acid), with six carbon atoms each, and marketed as an accessory for electronic equipment, has been used as alternative method for hemostasis in OSH [5,20]. Studies have highlighted some advantages over the conventional technique, such as: replacement of the hemostatic forceps and suture material in the ovarian and uterine stumps, decreased invasiveness, reduced surgical time and reduced final cost $[2,6,22]$. The Brazilian Veterinary Statutory Body (CFMV - Conselho Federal de Medicina Veterinária), according to the directive nr. 00371/2015/CFMV-PR, advised against its use in veterinary surgical procedures, due to reports of postoperative complications in the short and long term [4].

In Brazil, this device is not marketed as a surgical product, properly packaged and sterilized. Some international pharmaceutical companies already produce a clamp model that is suitable for surgical use, in accordance with the regulations of the responsible bodies, but that is still unavailable in the Brazilian market $[2,6,22]$.

There are many complications reported in the literature due to the use of the nylon clamp in OSH in bitches and female cats, such as bilateral hydronephrosis and hydroureter, perirenal granuloma, dehiscence, evisceration, hemorrhage, intestinal necrosis and peritonitis $[4,13]$.

Thus, the present report aims to present a case of iatrogenic foreign body, in a cat's bladder lumen after elective $\mathrm{OSH}$, and to discuss the use of nylon forceps as a hemostatic method in surgical procedures for pets.

\section{CASE}

A 1-year-old Persian female cat was assisted at the Veterinary Hospital of the Federal University of Jataí (UFJ), GO, Brazil. In the anamnesis, red urine was revealed, associated with low urinary volume and high frequency, with polyuria. It was reported that the patient underwent an OSH procedure, three months earlier, in a private clinic and, subsequently, an antibiotic, indicated by the veterinarian, was used for 30 days once there were cystitis symptoms.

On the physical examination, the patient presented pain at abdominal palpation and, subsequently, abdominal ultrasound tests, $\mathrm{CBC}, \mathrm{WBC}$ and urinalysis were requested to assist in the diagnosis. In the WBC, leukopenia and eosinophilia were observed, indicating a chronic inflammatory process installed. The urinalysis showed the presence of crystals, increased urinary density, milky aspect indicating presence of pus, proteinuria and hematuria. On ultrasound, the bladder presented a normal topography, partially filled with anechoic content, normal and preserved walls, but with two amorphous structures in the lumen, presenting acoustic shadow. These were approximately 0.4 and $0.6 \mathrm{~cm}$ in diameter, suggesting urolithiasis.

Considering the results, the patient was referred for cystotomy. According to the anesthetic protocol of HV-UFG, the association of acepromazine (Ace$\left.\operatorname{pran}^{\circledR} 0.2 \%\right)^{1}$ [dose of $0.02 \mathrm{mg} / \mathrm{kg}$ ], midazolam (Dormium $\left.^{\circledR}\right)^{2}$ [dose of $0.2 \mathrm{mg} / \mathrm{kg}$ ], morphine $\left(\text { Dimorf }^{\circledR}\right)^{3}$ [dose of $0.2 \mathrm{mg} / \mathrm{kg}$ ] and ketamine (Quetamina $\left.{ }^{\circledR}\right)^{1}$ [dose of $10 \mathrm{mg} / \mathrm{kg}$ ] was used intramuscularly as preanesthetic medication. For anesthetic induction, propofol (Provive $\left.^{\circledR}\right)^{2}$ [dose of $5 \mathrm{mg} / \mathrm{kg}$ ] were administered intravenously, in addition of epidural anesthesia with lidocaine $\left(\text { Xylestesin }{ }^{\circledR} 2 \%\right)^{3}$ [dose of $1 \mathrm{~mL} / 4 \mathrm{~kg}$ ] along with morphine $\left(\text { Dimorf }^{\circledR}\right)^{3}$ [dose of $0.1 \mathrm{mg} / \mathrm{kg}$ ]. For anesthetic maintenance, isoflurane in oxygen at $100 \%$ was used. Then, a 4-cm retro-umbilical incision was performed to exhibit the bladder. After the cystotomy, a rigid structure with approximately $0.8 \mathrm{~cm}$ (Figure 1) similar to a nylon clamp present in the bladder lumen was found and removed, and no urinary calculus, as suspected on ultrasound examination, was found. After

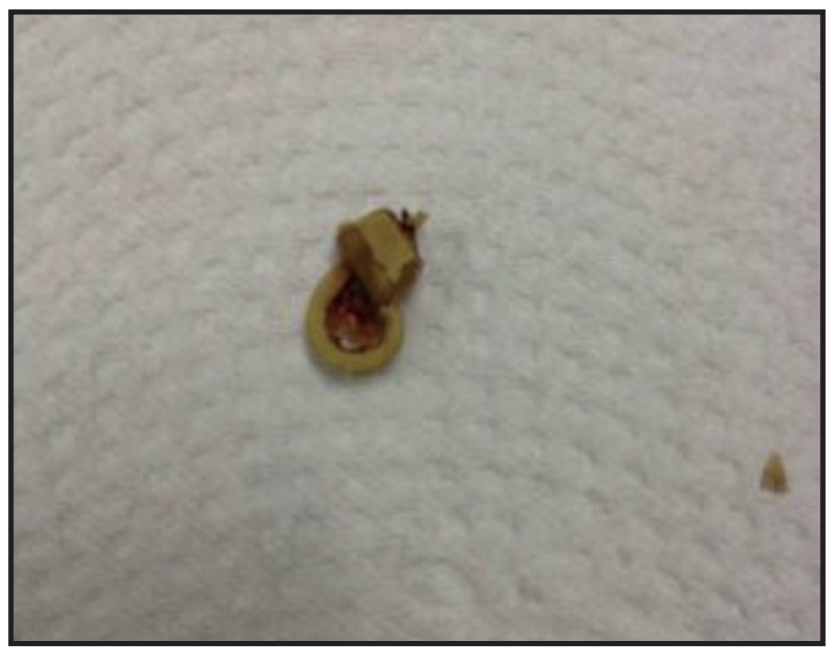

Figure 1. Photo of the foreign body removed from the urinary bladder of a 3-year-old female cat through cystotomy. It is a nylon clamp, similar to those used in electronic devices, with the conservation of the locking system, with about $0.8 \mathrm{~cm}$ in diameter. 
removal, the seromuscular synthesis of the bladder was made with 3-0 mononylon (Shalon ${ }^{\circledR}$ Nylon 3-0) ${ }^{4}$ simple continuous suture. For the synthesis of the muscle, a 2-0 mononylon (Shalon ${ }^{\circledR}$ Nylon 2-0) ${ }^{4}$ sulton standard thread was used. And finally, the synthesis of the skin was performed with a 2-0 mononylon (Shalon ${ }^{\circledR}$ Nylon $2-0)^{4}$ simple separated standard thread.

The postoperative treatment prescribed to the patient was: amoxicillin with potassium clavulanate (Agemoxi CL $\left.{ }^{\circledR}\right)^{5}$ [dose of $15.6 \mathrm{mg} / \mathrm{kg}$, orally, $12 / 12 \mathrm{~h}$, for 21 days], meloxicam (Maxicam $\left.{ }^{\circledR} 0.5 \mathrm{mg}\right)^{6}$ [dose of $0.12 \mathrm{mg} / \mathrm{kg}$, orally, $24 / 24 \mathrm{~h}$, for 4 days] and tramadol (Cronidor $\left.^{\circledR} 12 \mathrm{mg}\right)^{5}$ [dose of $5 \mathrm{mg} / \mathrm{kg}$, orally, 12/12 h, for 4 days]. After 10 days, the patient returned to remove the surgical stitches, showing good healing of the surgical wound and clinical improvement, with the remission of the symptomatology reported on anamnesis and physical examination.

\section{DISCUSSION}

In the routine of veterinary clinics, OSH is considered a simple surgery, even with its highly invasive character. However, some authors report recurring problems in this type of surgery, especially with the inappropriate use of nylon clamps, that can be identified immediately after the $\mathrm{OSH}$ procedure, or up to eight years later $[1,13]$.

Urinary system complications such as hydronephrosis and hydroureter due to the accidental ligature of the ureters by nylon clamps, incision of ureter instead of uterine body and urinary incontinence are reported [1].

About the use of clamps in OSH, were mentioned complications such as dehiscence, loose clamps and peritonitis due to contamination or error in the use of the technique [13]. Previous training with the use of clamps on simulators are indicated before using them in surgical procedures [6]. The same author mentions that the use of this device requires greater care for its use in OSH, and the use of needle holders and grasping forceps is inappropriate to lock it, causing malfunction of the device [6].

The migration of foreign bodies and intrauterine devices to the bladder is reported in women, although extremely uncommon, usually associated with vaginal penetration or use of intrauterine devices [8,11,16,18,19].

The pathophysiology of nylon clamp migration to the bladder could supposedly be explained in a similar way to the intravesical migration of intrauterine devices (IUDs) to the abdominal cavity, bladder and intestines, in women $[7,11,12,15]$. According to reports, it is a progressive event, in which several factors may be involved, mainly observing: inadequate implantation of the devices, uterine infections, inappropriate use of contaminated medical instruments, among others, followed by inflammatory process, perforation of the uterine wall by the device, adhesions and migration to adjacent structures [12,15].

In the present report, it is believed that the locking system of the clamp may have been flawed in the procedure performed by the veterinarian responsible for the OSH, which caused its loosening and detaching, and subsequent migration to the urinary bladder, organ located ventrally to the uterine body. However, the following hypotheses can also be raised: pregnancy at the moment of castration, followed by uterine stump retraction and release of the clamp; contamination of surgical instruments; postoperative infections and adhesions involving the bladder.

In bitches, hematuria was reported as a clinical sign of surgical complications by OSH and the presence of loose plastic seal among the intestinal loops, omentum and flow to the ovaries $[1,13]$. However, the migration to the urinary bladder was not found in the literature consulted. The tests performed as the ultrasonography and urinalysis to assist in definitive diagnosis are also mentioned $[1,13]$.

A case of urinary infection and subsequent bladder stone formation after the insertion of the levonorgestrel-releasing intrauterine system was reported in a woman [21]. The authors explained that the initial symptoms of cystitis may have occurred due to bladder perforation. Similarly, it is believed that the signs related to cystitis in the cat of this report are related to perforation of the urinary bladder, caused by migration of the nylon clamp. Probably, if the foreign body persisted in the bladder, it would lead to other complications, such as bladder stone formation [3].

It is known that intravesical structures, among which urolytes, can result in the visualization of hypoor anechogenic-type acoustic shadow-forming artifacts in the bladder ultrasonography [9]. For that reason, urolithiasis was the initial diagnosis. At ultrasonography (Figure 2), two juxtaposed, acoustic shadow-forming structures were visualized. They probably resulted from the part of the circular closed clamp and the 


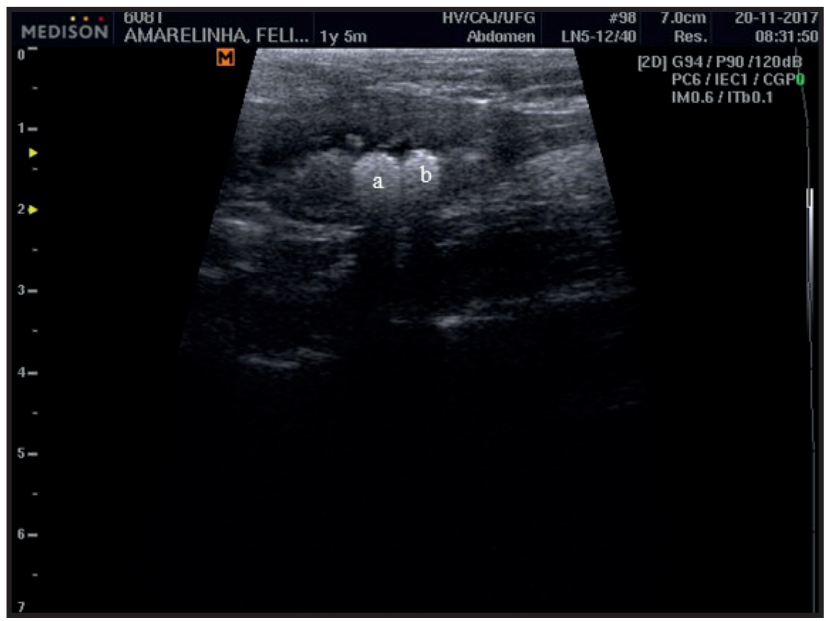

Figure 2. Image of ultrasound examination from the urinary bladder of a 3-year-old female cat, showing two acoustic shadow-forming circularshaped structures $(\mathrm{a}, \mathrm{b})$, measuring about 0.6 and $0.4 \mathrm{~cm}$ respectively.

sealing part of the clamp, which formed two distinct acoustic shadows.

The findings of the anamnesis and physical and complementary examinations indicated the presence of recurrent urinary infection and the need for uroculture and antimicrobial susceptibility testing (AST) [17]. Culture and AST of the removed foreign body would also be indicated [10]. However, the guardian did not authorize the exams. Thus, a broad-spectrum antimicrobial agent was chosen for the treatment [17].

Although there are already some studies, it is believed that the use of nylon clamp in OSH in female cats should be studied to quantify its durability, strength and reliability not to cause subsequent injuries to the patient. Veterinarians must also be trained to use this device, as the improper use of a hemostasis device can cause greater iatrogenic damage to the animal. And, despite the OSH being a routine procedure at the veterinary clinic, and being considered simple by many, it is an invasive surgery and, as any surgical procedure, deserves due care and awareness of professionals.

Thus, it was concluded that the use of nylon clamps in OSH of cats can lead to their migration to the bladder lumen, causing important urinary clinical changes. The ultrasound examination proved to be an important diagnostic complementary examination, but cystotomy confirmed to be the recommended diagnostic and therapeutic technique.

\section{MANUFACTURERS}

${ }^{1}$ Vetnil Indústria e Comércio de Produtos Veterinários Ltda. Louveira, SP, Brazil.

${ }^{2}$ União Química Farmacêutica Nacional S/A. São Paulo, SP, Brazil. ${ }^{3}$ Cristália Produtos Químicos Farmacêuticos Ltda. Itapira, SP, Brazil.

${ }^{4}$ Shalon Fios Cirúrgicos Ltda. São Luís de Montes Belos, GO, Brazil.

${ }^{5}$ Agener União Distribuidora de Medicamentos Ltda. São Paulo, SP, Brazil.

${ }^{6}$ Ouro Fino Saúde Animal Ltda. Cravinhos, SP, Brazil.

Declaration of interest. The authors report no conflicts of interest. The authors alone are responsible for the content and writing of the paper.

\section{REFERENCES}

1 Atallah F.A., Silva R.S., Ramos M.L.M., Oliveira A.L.A., França T.N. \& Brito M.F. 2013. Complicações póscirúrgicas em cadelas submetidas à ovariohisterectomia no Rio de Janeiro. Revista Brasileira de Medicina Veterinária. 35(1): 61-69.

2 Barros B.J., Sanches A.W.D. \& Pachaly J.R. 2009. Utilização de abraçadeiras de náilon 6.6 (poliamida) como método de ligadura de pedículos ovarianos e coto uterino em ovariohisterectomia eletiva em cadelas (Canis familiaris). Arquivos de Ciências Veterinárias e Zoologia da UNIPAR. 12(1): 47-60.

3 Bartges J.W. \& Callens A.J. 2015. Urolithiasis. Veterinary Clinics of North America: Small Animal Practice. 45(4): 747-768.

4 Brasil. 2015. Conselho Federal de Medicina Veterinária. Ofício nº 00371/2015/CFMVPR. Parecer técnico quanto a utilização de abraçadeiras de Nylon na realização de ligaduras vasculares em procedimentos cirúrgicos de pequenos animais. Brasília, DF. [Available at: <http:// www.crmvsp.gov.br/arquivo_midia/Parecer_Tecnico_CFMV_Uso_de_Abracadeira_de_Nylon.pdf $>$ ].

5 Colombi B.L. 2016. Polimerização da Poliamida 6,6: Uma Breve Revisão. Revista Eletrônica de Materiais e Processos. 11(3): 121-129.

6 Costa Neto J.M., Teixeira E.M., Ferreira Filho E.M., Toribio J.M.M.L., Almeida Filho C.H.R. \& Moraes V.J. 2009. Braçadeira de náilon para hemostasia preventiva na ovariosalpingohisterectomia em gatas. Revista Brasileira de Saúde e Produção Animal. 10(3): 615-624. 
7 Davoodabadi A., Mohammadzadeh M., Amirbeigi M. \& Jazayeri H. 2015. Invading of intrauterine contraceptive device into the sigmoid colon through uterine perforation caused by a blunt trauma. Chinese Journal of Traumatology. 18(4): 235-237.

8 Ebel L., Foneron A., Troncoso L., Cañoles R., Hornig A. \& Corti D. 2008. Migración de dispositivo intrauterino a vejiga: Aportación de cuatro casos. Actas Urológicas Españolas. 32(5): 530-532.

9 Gallego R., Arenas V. \& Ortiz J. 2019. Litiasis renal y vesical en un canino: descripción imagenológica. Revista de investigaciones veterinarias del Perú. 30(1): 507-511.

10 Gandolfi-Decristophoris P., Regula G., Petrini O., Zinsstag J. \& Schelling E. 2013. Prevalence and risk factors for carriage of multi-drug resistant Staphylococci in healthy cats and dogs. Journal of Veterinary Science. 4(4): 449-456.

11 Istanbulluoglu M.O., Ozcimen E.E., Ozturk B., Uckuyu A., Cicek T. \& Gonen M. 2008. Bladder perforation related to intrauterine devices. Journal of the Chinese Medical Association. 71(4): 207-209.

12 Jain N., Singh P., Chabbra A. \& Goel D. 2019. Lost IUCD since 14 years: found in urinary bladder. Scholars International Journal of Obstetrics and Gynecology. 2(5): 135-139.

13 Macedo A.S., Dal-Bó I.S., Quadros A.M., Brambatti G., Reis K.D.H.L., Brun M.V., Alievi M.M. \& Beck C.A.C. 2012. Complicações associadas à ovariosalpingohisterectomia eletiva realizada com abraçadeira de náilon como método de hemostasia. Acta Scientiae Veterinariae. 40(4): 1086.

14 Mesquita L.R., Rahal S.C., Matsubara L.M., Mamprim M.J., Foschini C.R., Faria L.G. \& Kano W.T. 2015. Bilateral hydronephrosis and hydroureter after ovariohysterectomy using nylon cable tie: a case report. Veterinární Medicína. 60(1): 53-56.

15 Mülayim B., Mülayim S., \& Yigit Celik N. 2006. A lost intrauterine device. Guess where we found it and how it happened? The European Journal of Contraception \& Reproductive Health Care. 11(1): 47-49.

16 Oguntayo O.A., Zayyan M., Odogwu K., Koledade K., Mbibu H., Bello A. \& Sani S. 2009. Foreign Body (Metallic Flashlight Cover) in the Urinary Bladder Mimicking Advanced Cancer of the Cervix: Case Report and Review of the Literature. African Journal of Urology. 15(2): 111-113.

17 Oh Y.I., Kim H.J., Kim Y.M., Kim S.S., Kim J.K., Kim H.W., Kang B.J. \& Youn H.Y. 2017. Antimicrobial resistance of bacterial isolates from positive urine culture in four hundred five dogs between 2013-2014. International Journal of Applied Research in Veterinary Medicine. 15(2): 99-107.

18 Pereira B.J., Coelho H., Brandão A., Borges R., Leão R., Grenha V., Peralta P. \& Sobral F. 2010. Migração transuterina transvesical espontânea de dispositivo intra-uterino. Acta Urológica. 4: 55-57.

19 Pérez G.V., García L.L.M., Serra A.G., Ariza A.M.J., Antón N.J.A., Almodóvar B.R. \& Serra P.A. 2001. Perforación uterina y migración vesical de un dispositivo intrauterino. Actas Urológicas Españolas. 25(6): 458-461.

20 Prado T.D. 2012. Braçadeira de poliamida e fio de náilon na ovariohisterectomia em gatas. 46f. Goiânia, GO. Dissertação (Mestrado em Ciência Animal) - Programa de Pós-Graduação em Ciência Animal, Universidade Federal de Goiás.

21 Rafique M., Rauf A., Khan N.A. \& Haque T.U. 2003. An unusual cause of vesical stone: a migrant intrauterine device. The European Journal of Contraception \& Reproductive Health Care. 8(3): 170-172.

22 Silva W.M. 2013. Eficácia da braçadeira de náilon como método hemostático na ovariosalpingohisterectomia de cadelas. Salvador, BA. 65f. Dissertação (Mestrado em Ciência Animal) - Programa de Pós-Graduação em Ciência Animal nos Trópicos. Universidade Federal da Bahia. 